\title{
Maciej Zweiffel
}

Uniwersytet Jagielloński

ORCID: 0000-0002-4010-3907

\section{Kompetencja literacka a rozumienie tekstów dziennikarskich}

\begin{abstract}
Streszczenie
Autor artykułu definiuje kompetencję literacką, a następnie na przykładzie odbioru fragmentu literackiego buduje jej model, oparty na hermeneutyce. Po tej części teoretycznej, analizując artykuł informacyjny oraz przekaz medialny, ukazuje przydatność kompetencji literackiej u odbiorze przekazów medialnych w ogóle.
\end{abstract}

Słowa kluczowe: kompetencja literacka, hermeneutyka, stopienie horyzontów, intersubiektywność.

\section{Literacy competence and understanding of jurnalistic texts}

\begin{abstract}
The author of the article defines literacy competence and on the example of interpreting a literary work builds the model of this competence, based on hermeneutics. After this theoretical part he, analysing one press article and one media message, presents how the literacy competence can be useful in the reception of messages in general.
\end{abstract}

Keywords: literacy competence, hermeneutics, fusion of horizons, intersubjectivity.

\section{Wprowadzenie}

Wyraz „kompetencja” od bodaj przełomu lat 50. i 60. XX wieku robi coraz to większą karierę. Zaczęło się prawdopodobnie od Noama Chomsky'ego i jego gramatyki generatywnej, w ramach której kompetencja językowa oznaczała wrodzoną umiejętność uczenia się języka i tworzenia coraz to nowych zdań. Nieco później Basil Bernstein rozuinął koncepcję kodów ograniczonego oraz rozbudowanego, uskazując na fakt, że ten pierwszy wpływa negatyunie na kompetencję poznawczą oraz społeczną jednostki ${ }^{1}$. Od lat 80. XX wieku niesamowitą karierę zaczyna robić termin „kompetencja kulturowa” (cultural competence) ${ }^{2}$. W rezultacie tej błyskotliwej kariery (w najpopularniejszej

\footnotetext{
${ }^{1}$ B. Bernstein, Socjolingwistyka a spoleczne problemy kształcenia w: Język i społeczeństwo, red. M. Głowiński., Czytelnik, Warszawa 1980, s. 110-111.

2 J.S. Gallegos, Ch. Tindall, S.A. Gallegos, The Need for Advancement in the Conceptualization of Cultural Competence, http://citeseerx.ist.psu.edu/viewdoc/download?doi=10.1.1.510.4302\& rep=rep1\&type=pdf, s. 1 (dostęp: 10.09.2018); H.K. Kohli, R. Huber, A.C. Faul, Historical and Theoretical Development of Culturally Competent Social Work Practice, „Journal of Teaching
} 
wyszukiwarce po upisaniu hasła cultural competence otrzymujemy aż 65200000 wyników - stan na 10.09.2018) Parlament Europejski oraz Rada Europy 18 grudnia 2006 roku wydali zalecenie „w sprawie kompetencji kluczowych w procesie uczenia się przez całe życie" (Zalecenie, 2006). Co zaś szczególnie istotne w śuietle prezentowanych rozważań, na pierwszym miejscu wśród tych kompetencji kluczouych widnieje „porozumiewanie się w języku ojczystym”3. W tym miejscu uypada zadać pytanie, co oznacza kompetentne porozumiewanie się w języku ojczystym.

W artykule oparto się na założeniu, że pełna kompetencja komunikacyjna w języku ojczystym ściśle wiąże się z rozumieniem tekstów literackich. Innymi słowy, kto nie rozumie literatury, operuje czymś na kształt kodu ograniczonego, przykładowo - nie rozpoznaje poprawnie przenośnego czy ironicznego charakteru danego przekazu. W polskim środowisku naukowym uskazane założenie pojauia się nieśmiało, częściej natomiast u praktyce szkolnej, kiedy to widać, że uczeń nieradzący sobie z literaturą z zakresu podstawy programowej nie rozumie także złożonych poleceń na innych przedmiotach, choćby matematycznych zadań z treścią. Odważniej do tej korelacji podchodzi National Endowment for the Arts, niezależna amerykańska agencja rządowa skupiona na wspieraniu kultury i sztuki, uskazując na zależność przyczynową między zmniejszającymi się umiejętnościami rozumienia przekazów literackich a coraz gorszym pojmowaniem tekstów w ogólet.

\section{Model kompetencji literackiej}

Aby uzmysłowić sobie, na czym może polegać kompetencja literacka, przedstawione zostanie przykładowe odczytanie utworu literackiego. Istnieje oczywiście wiele podejść do fenomenu literatury, od formalizmu po dekonstruktywizm, wybór sposobu odczytywania przekazu literackiego może zatem uydawać się trudny. Załóżmy jednak, że niezbędną kompetencję literacką wyznaczają wymagania egzaminu maturalnego z języka polskiego. A te, jeśli sięgniemy po materiały szkoleniowe dla egzaminatorów (piszący te słowa takim egzaminatorem jest), uskazują uyraźnie na hermeneutyczny model rozumienia literatury ${ }^{5}$. W wielkim uproszczeniu, interpretacja polega na spotkaniu się (stopieniu się horyzontów, Horizontverschmelzung w ujęciu H.G. Gadamera) horyzontu poznawczego odbiorcy (obejmującego świat wartości, doświadczenia etc.) z horyzontem dzieła, czyli jego historycznie rozumianym znaczeniem (znaczenie ahistoryczne, obiektywne przekazu stanowi utopię). Warto w tym miejscu zaznaczyć, że

in Social Work" 2010, no. 30(3), https://wuw.tandfonline.com/doi/full/10.1080/08841233.2010 .499091.

${ }^{3}$ Zalecenie Parlamentu Europejskiego i Rady z dnia 18 grudnia 2006 r. w sprawie kompetencji kluczowych w procesie uczenia się przez całe życie (2006/962/WE), https://eur-lex. europa.eu/legal-content/pl/TXT/PDF/?uri=CELEX:32006H0962, s. 4 (dostęp: 10.09.2018).

4 N.K. Hayles, How We Read: Close, Hyper, Machine, „ADE Bulletin” 2010, no. 150, s. 62.

${ }_{5}$ Przykładem tekst szkoleniouy dla egzaminatorów zamieszczony m.in. na stronie OKE Jaworzno autorstwa D. Szczukouskiego i G.B. Tomaszeuskiej, Sztuka interpretacji a lekcje polskiego, „Polonistyka” 2013, nr 16(11), s. 4-8. 
opowieści, jakoby to Wisława Szymborska nie zdała matury z interpretacji własnego wiersza, należy traktować z ogromnym dystansem, zułaszcza w świetle tak zwanej nowej matury. Jej formuła nie ma niczego uspólnego z interpretacją według klucza, wymaga się tylko intersubiektywnie komunikowanego dialogu z dziełem na podstawie kontekstów historycznych (przypominam - chodzi o historycznie ujmowane znaczenie).

Skoro już zostanie zarysowany model kompetencji literackiej, przejdziemy do ilustracyjnego zastosowania tych narzędzi w odbiorze tekstu dziennikarskiego oraz medialnego (karykatury, czyli tak zwanego tekstu kultury). Pokażemy, na ile elementy kompetencji literackiej mogą być zaangażowane w odbiór komunikatów prasowych. Określimy również użyteczność założeń hermeneutycznych w interpretacji przekazu ikonicznego.

Pisząc o rozumieniu tekstu, musimy uwzględniać nie tylko wyabstrahowany proces umysłowy (pojmowanie czegoś), ale także samo dzieło (przedmiot) oraz jego obecność u rozumieniu. Mamy więc do czynienia z realizowaną w czasie jednością tych trzech składników: podmiotu, przedmiotu i rozumienia zbliżającego do siebie te instancje. Nie można więc podać jakiejś metody rozumienia in abstracto, dlatego H.G. Gadamer pisze u Prawdzie i metodzie: „To, co humanistykę czyni nauką, daje się zrozumieć raczej na podstawie tradycji pojęcia kształcenia niż na podstawie metody nowoczesnej nauki" . W efekcie relacja między podmiotem a przedmiotem nie może mieć wyraźnie zarysowanych granic (inaczej niż np. przy badaniu preparatu z jakiejś tkanki), gdyż interpretujący angażuje się u swój przedmiot. Ma to związek z samą naturą rozumianego fenomenu literackiego, który nie istnieje jako obiektyuna rzecz. Dla przykładu - konkretny egzemplarz Pana Tadeusza stanowi zaledwie nośnik tego dzieła, a ono samo istnieje tylko w lekturze. Zakrzepła w tekście fizycznym (nośnik) komunikacja potrzebuje jakiegoś sprawcy, który jako rozumiejący czytelnik dzieła sprawi, że zaistnieje ono u swoim wartościowo-komunikacyjnym byciu.

Interpretacja powinna zatem być środkiem komunikowania, porozumiewania się czytelnika i dzieła, „miejscem wspólnym” tych, jak pisze Gadamer, duóch horyzontów:

Fenomen hermeneutyczny zawiera u sobie pierwotność rozmouy i strukturę pytania i odpowiedzi. To, że przekazany przez tradycję tekst staje się przedmiotem interpretacji, oznacza już, że stawia on pewne pytanie interpretatorowi (daje coś do zrozumienia - uzup. M.Z.). Dlatego interpretacja z istoty odsyła zausze do postawionego danej osobie pytania. Rozumieć tekst oznacza rozumieć to pytanie. To zaś następuje [...] dzięki uzyskaniu horyzontu hermeneutycznego. Rozpoznajemy go teraz jako horyzont pytania, horyzont, w obrębie którego określa się kierunek sensu tekstu?

Oczywiście ten „horyzont sensu tekstu” jest właściwie rozwijany z miejsca, w którym krzyżują się drogi dwóch otwartych pytań - nadawcy i odbiorcy.

\footnotetext{
${ }^{6}$ H.G. Gadamer, Prawda i metoda: zarys hermeneutyki filozoficznej, tłum. B. Baran, Inter Esse, Kraków 1993, s. 49.

7 Tamże, s. 343-344.
} 
Dążenie do takiego „spotkania”, porozumienia się co do czegoś, w tym przypadku dzieła, jest całkouicie przeciune postawie narcystycznej, skupieniu na sobie, używaniu tekstu. Narcyz, czyli ktoś zauroczony swoim wizerunkiem, o nic właściwie nie pyta, tym samym nie ma dla niego nic „do zrozumienia”. Ten bohater mityczny nie podejmuje wysiłku „zmącenia” gładkiej prezentacji i szukania głębi. Tylko patrzy (poziom nośnika, tego, co dane zmysłowo), nie wypowiada słowa, aż milknie na zawsze. Nie ma dla niego pytania, otwarcia perspektywy w głąb, tylko zupełność spostrzeżenia - dlatego nie rozumie. Dlatego dzieło sztuki literackiej, aby nie być prostą bezpośredniością (nośnikiem, tj. pismem, dźwiękiem), potrzebuje czytelnika. Ale także ten ostatni, żeby uchronić się przed stagnacją, potrzebuje wejść w orbitę przekazanego przez tradycję pytania i starać się nawiązać rozmowę - interpretację. Nawet jeśli sprowadzi się interpretację do rangi osobistego przeżycia, to będzie ono miało charakter pytania o interpretatora - nie o kogoś oderwanego od lektury, ale istniejącego u świetle rozumianego tak a nie inaczej świata przedstawionego $w$ utworze.

Warto $\mathrm{w}$ tym miejscu $\mathrm{w}$ punktach przedstawić warunki wyjściowe rozumienia dzieła literackiego, pokazując jednocześnie ewentualne związki z odbiorem tekstów dziennikarskich:

1. Niebezpośredniość i zadaniouy charakter utworu. Oznacza to, że nie istnieje on jako coś bezpośrednio danego (nośnik), a wymaga wysiłku lektury. Oczywiście dotyczy to uszystkich tekstów, także tak zwanych tekstów kultury (obrazu, rzeźby, filmu etc.). Zróżnicowane będą skala i wymiar tej zadaniowości - notatka prasowa sprowadza się ułaściwie do czystej informacji, dającej się zastąpić ewentualną obecnością u czasie danego uydarzenia, trudność rośnie przy na przykład reportażu czy recenzji.

2. Zaangażowany charakter poznawania dzieł - czytanie jako kształcenie się. Nie czytam zatem tylko po to, by zmagazynować w swoim mózgu kolejne porcje informacji, lecz mając na uwadze formowanie określonego stosunku do świata i swojego w nim miejsca. Jeśli znów weźmiemy pod uwagę reportaż, to i ten etap odczytania będzie jak najbardziej na miejscu8. Podobna sytuacja pojawi się przy odbiorze nieograniczonego już do jakiegoś jednego gatunku prasowego dziennikarstwa zaangażowanego (engaged journalism), w ramach którego często mówi się informowaniu jako rozmowie 9 .

3. Odbiór dzieła ujmowany jako spotkanie i uzgadnianie horyzontów czytającego i utworu. Ten punkt szczególnie odnosi się do tych form dziennikarskich, które wykraczają poza (mniej lub bardziej nacechowane politycznie) referowanie faktów, kiedy przekaz uykracza poza „tu i teraz”, historyczną doraźność, stając się

${ }_{8}^{8}$ A. Kaliszewski, E. Żyrek-Horodyska, Kilka uwag o metodach analizy tekstów dziennikarskich [w:] Metody badań medioznawczych i ich zastosowanie, red. A. Hess, M. Lisouska-Magdziarz, A. Szymańska (red.), ToC, Kraków 2018; H.K. Kohli, R. Huber, A.C. Faul, Historical and Theoretical Development of Culturally Competent Social Work Practice, „Journal of Teaching in Social Work" 2010, nr 30(3), https://wuw.tandfonline.com/doi/full/10.1080/088 41233.2010.499091, s. 130-131.

9 B. DeJarnette, 5 Ways „Engaged Journalism” Made Progress in 2016, http://mediashift. org/2016/12/5-ways-engaged-journalism-movement-made-progress-2016/ (dostęp: 11.09.2018). 
np. świadectuem, ostrzeżeniem etc. I znouu przywołamy reportaże, ale też wywiady, wywiady-rzeki, relacje (by nie posiłkować się oczywistymi nazwiskami Zofii Nałkouskiej, Hanny Krall i Ryszarda Kapuścińskiego, uspomnę Filipa Springera czy Filipa Niedanthala ${ }^{10}$ ).

4. Rozwijane w lekturze znaczenia, sensy i wartości (znaczenia wiążmy ze słounikiem, natomiast sensy odsyłają do poziomu pojęć, sposobu przedstawienia świata etc.) stanowią efekt czytelniczego spotkania z tekstem, konkretyzacji (w terminologii R. Ingardena) pewnych możliwości znaczeniowych zawartych w językouym kształcie dzieła. Przed „możliwościami” pojawił się wyraz „pewnych”, gdyż odczytanie utworu to wypadkowa horyzontu interpretacyjnego odbiorcy i horyzontu dzieła. Innymi słowy, nikt nie czyta dzieła samego w sobie, gdyż to istnieje tylko w odczytaniach. Nie ma przy tym dowolności interpretacyjnej, gdyż język, budowa, chuyty i konwencje składające się na warstuy tekstu funkcjonują w roli warunków brzegouych, oddzielających nadinterpretacje (nadużycie) od interpretacyjnego dialogu. Dlatego na przykład przy potraktowaniu Testamentu mojego Juliusza Słowackiego jako sielanki nie można mówić o stopieniu horyzontów czytającego i dzieła, znalezieniu miejsca uspólnego.

Przedstawione punkty odniesione do podmiotu pozwalają wyszczególnić podstawowe etapy procesu rozumienia. Niebezpośredniość utworów implikuje „wniknięcie (podkreślenie - M.Z.) w obiekt, którym jest dzieło"11, odczytywanie czy też konkretyzacja musi wiązać się z naśladowaniem, postępowaniem za dziełem. „Utwór [...], rozwijając przed nami stopniowo [...], umożliwia w ten sposób odtworzenie pewnego kompleksu przeżyć (nie poety, lecz związanych z wielowarstwowym światem przedstawionym M.Z.)"12. Naśladowanie utworu skorelowane jest z przeżyciem odtwórczym, co już wiąże się z tym, jak horyzont czytelnika stapia się z dziełem. Znaczenia czy sensy utworu mogą być bez „odzeuu” czytającego, pozostając uciąż potencjalnością. Na koniec mamy wykładnię, czyli wytłumaczenia „tak a nie inaczej” naszej interpretacji. Zatem uniknięcie, naśladowanie, przeżycie odtwórcze i wykładnia to cztery momenty intersubiektyunie komunikowalnego rozumienia utworu literackiego.

\section{Kompetencja literacka w działaniu I - odbiór tekstu literackiego}

Spróbujmy zastosować uszystkie te składowe rozumienia w odczytaniu następującego fragmentu:

\footnotetext{
${ }_{10}$ Np. teksty 13 pięter F. Springera, 13 pięter, Wydawnictwo Czarne, Wołowiec 2015 czy Apokalipsa teraz F. Niedenthala zamieszczony u publikacji E. Nowosielska, U. Szydłouska, Zrozumieć świat. Klasa 1. Podręcznik do języka polskiego dla zasadniczej szkoły zawodowej, Nowa Era, Warszawa 2015, s. 67-69.

11 H.G. Gadamer, Prawda i metoda..., op, cit., s. 225.

12 Tamże, s. 226.
} 
Maciej Zweiffel

„Król Edyp ma może

o jedno oko za wiele"13.

Zbadajmy, jak przebiega tutaj wniknięcie. Kim jest król Edyp - ciągiem widzianych liter, pustą nazwą? Wtedy jednak go nie ma, nie pojawia się również zacytowany przekaz literacki jako coś wartego zrozumienia, komentującego sytuację tego bohatera mitycznego w chwili odkrycia tragicznej prawdy - dlatego ma jedno oko więcej, choć przecież wykłuł sobie oba. Nie tylko przechodzimy od nośnika do znaczenia, łączymy „oko” (nośnik) ze zdolnością widzenia. Idziemy dalej - „oko” wykracza poza zmysłowość i staje się metaforą poznania u ogóle (poziom sensów). Rozuijanie wersów odkrywa ich znaczenie, a zarazem „zachouruje” (zatrzymuje) króla Edypa jako kogoś żywego, dziejącego się. Poustaje relacja między tym krótkim tekstem, czytanym „nośnikiem” a przywoływaną historią mityczną. Rozumienie tego zuiązku przybliża czytającemu losy Tamtego. Horyzont tego krótkiego fragmenciku rzutuje na odczytanie końca mitu o Edypie. Ten mit czy też słynna tragedia autorstwa Sofoklesa otrzymuje puentę autorstua niemieckiego poety. Wskazany zuiązek znaczeniouy między tym romantycznym duuwierszem a antycznym dziełem zarysouuje się w interpretacyjnym spotkaniu. Pozuala ono spojrzeć uspółczesnemu odbiorcy na losy króla Teb. Można powiedzieć, że $u$ akcie rozumienia życie, los czytającego krzyżuje się z losem antycznego władcy. Przez moment mają oni zatem uspólny los. Jak on się przedstawia? Co się dzieje, kiedy człowiek ma „o jedno oko za wiele”?

Takie pytanie nasuwa nam dzieło, przechodzimy więc do momentu naśladowania. Choć faktycznie jesteśmy oddaleni o kilka tysięcy lat od realiów przywoływanego mitu, to dzięki temu poetyckiemu fragmentowi możemy iść po śladzie mitycznego Edypa. „Jedno oko za wiele” oznacza - oczywiście u powiązaniu z na przykład tragedią Sofoklesa - „wiedzieć zbyt wiele”. Pozostając w granicach horyzontu tego dystychu Friedricha Hölderlina, na nowo odczytamy antyczną opowieść. Romantyczny poeta zapewne (to nasz horyzont, znających nieco romantyzm) chciał podkreślić tragizm tej postaci oraz dramat ludzkiej wiedzy (pamiętajmy - mit Fausta, wielkie dokonanie tej epoki, poznawane $w$ ramach szkolnej kompetencji literackiej, dotyczy między innymi wiedzy i zuiązanego z nią bólu istnienia). Ale możemy jeszcze ten horyzont rozszerzyć o doświadczenia totalitaryzmów XX wieku, by mocniej uświadomić sobie, że czasem lepiej pewnych rzeczy nie wiedzieć. Widać, jak przed Edypem otwiera się tragiczny sens życia - człowiek jako istota poznająca zostaje przygnieciona własnym poznaniem. Na szczęście my to przeżywamy w ramach rozumienia duuwiersza napisanego przez Hölderlina. Wspomniane nasze horyzonty i perspektywa romantycznego spojrzenia na losy tebańskiego króla pozwalają wyznaczyć miejsce uspólne nas i odczytywanego fragmentu. To stopienie horyzontów zamyka się w stwierdzeniu tragiczności ludzkiego życia. W tym momencie naśladowanie dzieła przechodzi w fazę przeżycia odtwórczego.

Ten miniaturowy wiersz niemieckiego twórcy ma ustrząsnąć odbiorcą. Przecież „jedno oko za wiele” dotyczy człowieka, który właśnie uykłuł sobie oczy spinkami żony

${ }_{13}$ M. Heidegger, Hölderlin i istota poezji, „Twórczość” 1976, nr 5, s. 100. 
i matki zarazem. Ta zaś sama się powiesiła. Ale dzięki takiemu tragicznemu sprzężeniu mamy szansę przeżycia katharsis (dlatego został użyty wyraz „dzięki”, przywołujący coś dobrego). Taki los nas przeraża, ale mając świadomość choćby najnouszej historii, wiemy, że tak jest, godzimy się z takim bolesnym wymiarem naszej egzystencji. Przeżywanie oznacza sprowadzanie dystansu czasowego do zera, stąd zamiast czasu przeszłego (np. „miał”) bardziej odpowiedni jest praesens historicum, czyli forma „ma”. Przeżywając przekazane przez tradycję świadectwo, łącząc w odtwarzaniu nasze teraz z tym przekazem, rozumiemy, że te dzieje są także o nas, o tobie i o mnie - de te fabula narratur, by przywołać znane powiedzenie łacińskie.

Ostatnim aktem procesu rozumienia jest sformułowanie czy też nałożenie na uniknięcie, naśladowanie i przeżycie wyktadni, tłumaczącej, gdzie lektura nas zaprowadziła oraz dlaczego tak się stało. W naszym przypadku uykładnia przebiegała równolegle do opisu podmiotowego spotkania z przekazem literackim. Dzięki temu hermeneutyczne odczytanie utworu staje się intersubiektyunie komunikowalne. I choć nie ma waloru obiektywności, to może podlegać dalszej dyskusji. W uykładni, jak było łatwo zauważyć, dochodzi do słowa historyczne ja (widać to w przywoływaniu horyzontu związanego z doświadczeniami hitleryzmu i stalinizmu). Jest więc ona historyczna (i choćby w tym sensie obiektywna być nie może), ale nie mamy tutaj do czynienia z zamknięciem się w peunej epoce. Rozumiejąc, staramy się znaleźć miejsce uspólne, Gadamerouskie stopienie horyzontów, co przyczynia się między innymi do ciągłości kultury.

\section{Kompetencja literacka w działaniu II - vjęcie przekazów prasowych i medialnych}

Wracając do pojęcia kompetencji, zaproponowane w ramach hermeneutyki podejście do przekazów literackich (a szerzej - uszystkich tekstów kultury) przyczynia się do zwiększania kompetencji kulturowej jednostek. Po prostu w większym stopniu wiemy, kim jesteśmy, jakie jest nasze dziedzictuo czy też obciążenie. Tym samym zastosowanie tego postępowania także $\mathrm{w}$ odniesieniu do tekstów dziennikarskich zasługuje na nieco uwagi. Na przykładzie uskażmy zatem jego ewentualne zalety i słabości, przy czym przedstawiona analiza przykładu nie ma charakteru dowodu, a jedynie ilustracji.

Weźmy typouy artykuł związany z działem wiadomości. Dobrany na potrzeby prezentowanych rozważań pochodzi z wrocłauskiej „Gazety Wyborczej” i nosi tytuł Kurier odmówit wejścia do siedziby „GW” $i$ został bohaterem prawicy ${ }^{14}$. Tekst stanowi klasyczny przykład artykułu informacyjnego, jakich dziesiątki ukazuje się każdego dnia $\mathrm{w}$ prasie drukowanej oraz sieci. Oczywiście ta konstatacja nie ma charakteru wartościującego, uskazuje tylko na typ przekazu. Można więc zapytać, po cóż przy lekturze

${ }_{14}$ M. Grocholski, Kurier odmówił wejścia do siedziby „GW” $i$ został bohaterem prawicy, Wyborcza.pl, 24 października 2016, http://wroclaw.uyborcza.pl/wroclaw/1,35771,20883062,kurier-nie-dostarczyl-przesylki-do-gu-i-zostal-bohaterem-prawicy.html (dostęp: 12.09.2018). 
takiej wiadomości z Wrocławia przywoływać jakąkolwiek kompetencję literacką, nie mówiąc już o narzędziach hermeneutycznych.

Aby uskazać u tym konkretnym przypadku bezcelowość sięgania po narzędzia wiążące się z wiedzą o literaturze, należy udowodnić okazjonalny, doraźny charakter tekstu. To zaś oznacza, że cel tego przekazu sprowadza się tylko do referowania konkretnych wypadków. Nie stawia on czytelnikowi żadnego pytania, jest przeźroczysty w tym sensie, że kiedy poznamy już relacjonowane fakty, lektura kończy się. Efektem wniknięcia w tekst okazuje się utedy wyłącznie uzyskanie określonej porcji informacji o jakimś urocłauskim kurierze i jego zachowaniu.

Omawiany tekst realizuje korespondencyjną definicję prawdy, czyli wszystkie jego zdania mają wartość prawdy (1) albo fałszu (0), pomijając drobne elementy wartościujące czy opiniujące dany fakt, na przykład „Co ciekawe, link do artykułu z naszego portalu zamieszczono na stronie facebookowej Narodoucy RP". Wyrażenie „co ciekawe” ujaunia zaskoczenie zespołu redakcyjnego „GW” zdarzeniem referowanym u następującym po nim zdaniu (możemy mu przypisać już uartości 1, jeśli faktycznie tak się stało).

Ten prawdziwościouy charakter elementów tekstu nie zawiesza sensowności użycia odniesień literackich (mamy wszakże literaturę faktu). Może się tak dziać jednak, gdy komunikat zbliża się do bezosobowego protokołu zdarzeń. Im bardziej przypomina taki protokól, w tym większym stopniu nie stawia odbiorcy przed jakimś sposobem widzenia świata czy światem przedstawionym.

A co zrobić, jeśli przypadkiem (np. autor nieświadomie nawiązał do literatury) bądź celowo w tekście występują słowa kluczowe dla jakichś kontekstów literackich? Oto przykład z czytanego artykułu:

Z kolei na stronie Dorzeczy.pl czytamy o «zbuntowanym kurierze», w komentarzach pod tekstem możemy przeczytać «że tak powinni postępować uszyscy w stosunku do zdrajców». [...] Ale w komentarzach czytelników tegoż portalu oprócz wielu słów aprobaty dla postawy «bohaterskiego» kuriera pojawiają się także opinie, że powinien on zostać zwolniony. Ale Maciej Świrski, doradca wicepremiera i ministra kultury Piotra Glińskiego, na suoim Twitterze zaapelował o pisanie listów do centrali firmy kurierskiej w obronie «bohaterskiego kuriera».

Łatuo domyślić się, że uyrażenia „zbuntowany kurier”, „bohater”, „bohaterski kurier" i „zdrajcy” oraz używany w zuiązku z nimi u roli dystansującej cudzysłów (przy okazji też wydzielający cudze słowa) potrzebują minimalnej choćby kompetencji literackiej. Mogą to być jakieś okruchy wiedzy o romantyzmie (np. zuiązanej z III częścią Dziadów) czy literaturze wojennej (weźmy Kamienie na szaniec). Podkreślone wyrazy w zestawieniu z opisem sytuacji zaczynają sugerować odbiorcy pytanie, czy kurier odmawiający doręczenia dziennikarce „GW” zamówionego obiektyuu to faktycznie współczesny spadkobierca tradycji Konrada bądź Rudego. Zaczyna zatem zarysouyuać się jakiś horyzont tego przekazu, poustaje on ułaściwie dzięki autorskiemu dystansowi 
do heroizacji (konteksty literackie) zuykłego niewykonywania obowiązków służbowych (zgodny z rzeczywistością opis zdarzeń).

Wracając do naszego pytania o przydatność narzędzi literaturoznawczych w odniesieniu do zuykłych wiadomości, nie odpowiemy już zdecydowanie, że są niepotrzebne. Mogą się przydać, co pokazał omawiany przykład. W czytanym tekście bowiem kompetencja literacka kształtowana u szkole podstawowej i na początku średniej (7-8 klasa, dawna 3 gimnazjum; 2 klasa liceum czy technikum) pozwalała uyraźnie zrozumieć zawarty w omawianym artykule dystans do postaw jakoby patriotycznych.

Oczywiście istnieje wiele notek prasowych, artykułów czy wiadomości, przy odbiorze których opisywana kompetencja pozostaje niejako w uśpieniu. Aby uzmysłowić sobie, kiedy aktywizuje się ona, a jakich sytuacjach pozostaje uśpiona, posłużmy się prostym schematem graficznym.

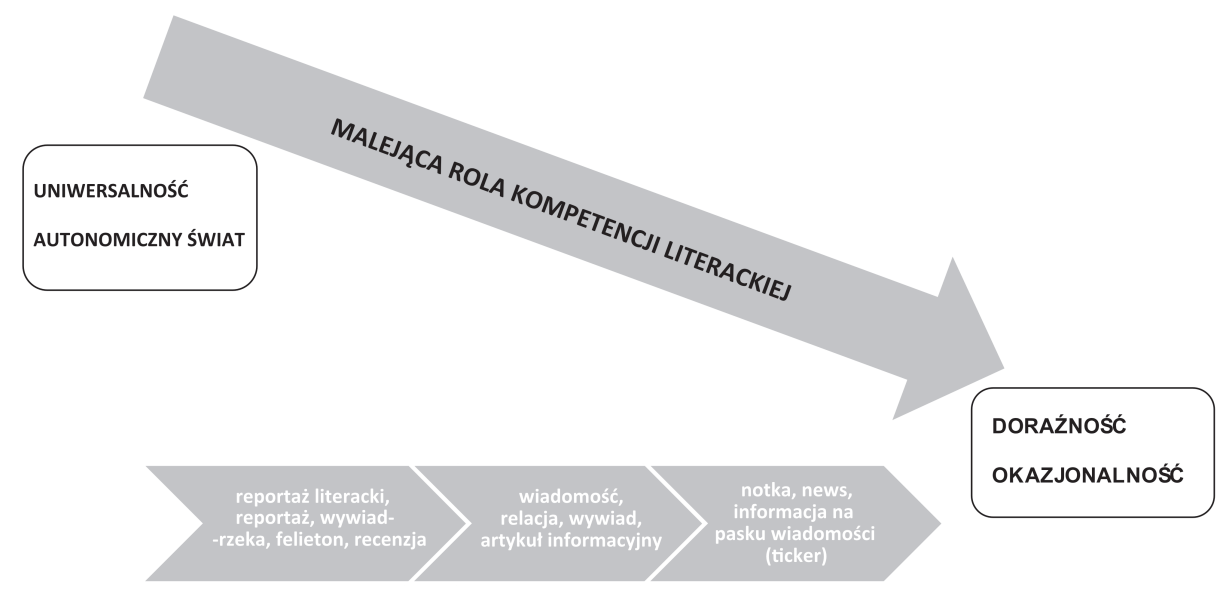

Rycina 1. Funkcjonowanie kompetencji literackiej

Źródło: opracowanie własne.

Jak widać, im bardziej dany przekaz ograniczony do prostego referowania faktów, tym mniej potrzeba literackich odniesień. Jeśli powiążemy to z przykładami gatunków dziennikarskich, to oczywiście reportaż literacki umieścimy najbliżej bieguna uniwersalności i dużej roli kompetencji odbiorczych łączących się z literaturą, natomiast w zupełności bez tejże kompetencji obejdą się newsy czy informacje z paska wiadomości.

Hermeneutyczne podejście do odbioru tekstów prasowych czy w ogóle przekazów medialnych wydaje się także zasadne ze uzględu na nieuspominaną dotychczas rolę przesądów u rozumieniu komunikatów. Wynika ona z omawianego już faktu, że $\mathrm{w}$ hermeneutyce odbiorca przekazu, nawet badając sine ira et studio, pozostaje istotą historyczną i włącza w proces rozumienia swój bagaż doświadczeń, wiedzy, przed-sądów (das Vor-urteil) czy przesądów ${ }^{15}$. W zetknięciu z dziełem to nasze nastawienie ulega

15 J. Maciejeuski, Pawet Dybel, „Granice rozumienia i interpretacji. O hermeneutyce Hansa-Georga Gadamera” (recenzja), „Studia z Historii Filozofii” 2015, nr 3(2), s. 220. 
pewnym modyfikacjom, wchodzi $\mathrm{w}$ korelację z horyzontem utworu, nie pozostaje już takie samo. Ktoś może $\mathrm{w}$ tym miejscu zadać pytanie, co z odczytaniami ideologicznymi, rażąco tendencyjnymi, służącymi jakiemuś ustalonemu z góry (poza procesem rozumienia tego dzieła) celowi. Mamy utedy, odwołując się do wcześniejszych uwag, nie rozumienie tekstu, ale jego użycie, narcystyczne potraktowanie (ktoś widzi u nim tylko siebie, swoje poglądy). W skrajnych zaś przypadkach, obejmujących fanatyczne bądź spiskowe podejście, kończy się jakakolwiek humanistyka, a zaczyna po prostu pole działania psychiatrii.

Aby zobaczyć, jak funkcjonują założenia bądź przesądy, z jakimi przystępujemy do rozumienia tekstu, sięgnijmy po przekaz medialny - karykaturę autorstwa Marka Knighta przedstawiającą tenisistkę Serenę Williams. Rysunek dotyczy jej zachowania w czasie tegorocznego finału (2018) US Open. Został on (oczywiście rysunek, nie finał) przez wielu odbiorcóu w USA okrzyknięty mianem rasistouskiego ${ }^{16}$. Według wypowiedzi krytyków analizowanego dziełka karykaturzysta zawinił tym, że przedstawił Amerykankę jako typową, rozgniewaną czarnoskórą kobietę, rysując jej np. bardzo pełne, uydatne usta ${ }^{17}$. Jeśli ten zarzut zestawimy z samą istotą karykatury, nie może nas zdziwić wyolbrzymienie czy też sięganie po typowe cechy kogoś. Zapytajmy zatem, dlaczego te wyolbrzymione, typowe cechy zostały odczytane jako rasistowskie. Dla uproszczenia skupmy się na karykaturalnie wyolbrzymionym wizerunku ust. W odniesieniu do Sereny Williams ten chuyt rysunkowy okazał się dla wielu jedną z przesłanek oskarżycielskich. Dlaczego natomiast na przykład w przypadku rysunków przedstawiających Micke'a Jaggera ten sam uybór estetyczny nie budził kontrowersji, a stał się nawet symbolem całego zespołu?

Z pomocą w rozwiązaniu tego problemu przychodzi nam hermeneutyka uskazująca na fakt, że w procesie rozumienia spotykają się ze sobą konkretna, historyczna osoba, dysponująca określoną wiedzą, doświadczeniem i wynikającymi z tego przesądami uzasadnionymi bądź nie, fałszywymi lub prawdziwymi - to wszystko wyjaśnia się w interpretacji. W ramach horyzontu odbiorców oskarżających o rasizm autora omawianej karykatury podkreślenie cech charakteryzujących osobę czarnoskórą nie pełniło funkcji uyróżniających, a poniżające. Zapewne dziedzictwo historyczne, ujauniające się w kompetencjach kulturowej czy literackiej uruchamianych przy okazji takich odczytań, wciąż pozostaje zbyt trudne do okiełznania, nabrania dystansu. Podobnie zapewne działoby się w polskich mediach, gdyby jakiś satyryk wyśmiewał kogoś, posługując się jakimiś wizualnymi cechami podkreślającymi czyjeś pochodzenie żydouskie. Śuiadczy to także o nieporadzeniu jeszcze sobie nad Wisłą z bolesnym dziedzictuem II wojny.

${ }^{16}$ M. Nowak, US Open: wściekta Serena Williams bohaterka karykatury. Pojawity się oskarżenia o rasizm, SPORT.TVP.PL, 11.09.2018, https://sport.tvp.pl/38944691/us-open-usciekla-serena-williams-bohaterka-karykatury-pojawily-sie-oskarzenia-o-rasizm (dostęp: 14.09.2018). ${ }_{17}$ Serena Williams Cartoonist Mark Knight Defends 'Racist' Image, materiał filmowy, 2018. Warto też prześledzić komentarze znajdujące się pod tym materiałem. 


\section{Podsumowanie}

Podsumourując rozważania dotyczące kompetencji literackiej i jej roli w odbiorze tekstów dziennikarskich (a także ogólnie - medialnych), można stwierdzić, że zbiór narzędzi zawierających kompetencję literacką, a w tym elementy podejścia hermeneutycznego, obejmuje obok przekazów czysto literackich także i te, ukazujące się u codziennej prasie. I choć nie każdy tekst stawia takie uymagania, to jednak zawsze warto w zanadrzu posiadać narzędzia poszerzające rozumienie przekazów.

\section{Bibliografia}

Bernstein B., Socjolingwistyka a społeczne problemy kształcenia [w:] Język i społeczeństwo, red. M. Głowiński, Czytelnik, Warszawa 1980, s. 83-119.

DeJarnette B., 5 Ways „Engaged Journalism” Made Progress in 2016, http://mediashift. org/2016/12/5-ways-engaged-journalism-movement-made-progress-2016/ (dostęp: 11.09.2018).

Gadamer H.G., Prawda i metoda: zarys hermeneutyki filozoficznej, tłum. B. Baran, Inter Esse, Kraków 1993.

Gallegos J.S., Tindall Ch., Gallegos S.A., The Need for Advancement in the Conceptualization of Cultural Competence, http://citeseerx.ist.psu.edu/viewdoc/download?do$\mathrm{i}=10.1 .1 .510 .4302 \& \mathrm{rep}=$ rep1\&type=pdf (dostęp: 10.09.2018).

Grocholski M., Kurier odmówił wejścia do siedziby „GW” $i$ został bohaterem prawicy, Wyborcza.pl, 24 października 2016, http://uroclaw.wyborcza.pl/wroclaw/1,35771,20883062,kurier-nie-dostarczyl-przesylki-do-gw-i-zostal-bohaterem-prawicy.html (dostęp: 12.09.2018).

Hayles N.K., How We Read: Close, Hyper, Machine, „ADE Bulletin” 2010, nr 150.

Heidegger M., Hölderlin i istota poezji, „Twórczość” 1976, nr 5.

Kaliszeuski A., Żyrek-Horodyska E., Kilka uwag o metodach analizy tekstów dziennikarskich [w:] Metody badań medioznawczych i ich zastosowanie, red. A. Hess, M. Lisouska-Magdziarz, A. Szymańska, ToC, Kraków 2018.

Kohli H.K., Huber R., Faul A.C., Historical and Theoretical Development of Culturally Competent Social Work Practice, „Journal of Teaching in Social Work”, 2010, nr 30(3), https:// uwu.tandfonline.com/doi/full/10.1080/08841233.2010.499091 (dostęp: 14.09.2018).

Maciejeuski J. Pawet Dybel, „Granice rozumienia i interpretacji. O hermeneutyce Hansa-Georga Gadamera” (recenzja), „Studia z Historii Filozofii” 2015, nr 3(2).

Niedenthal F., Apokalipsa teraz [w:] E. Nowosielska, U. Szydłouska, Zrozumieć świat. Klasa 1. Podręcznik do języka polskiego dla zasadniczej szkoły zawodowej, Nowa Era, Warszawa 2015, s. 67-69.

Nowak M., US Open: wściekła Serena Williams bohaterka karykatury. Pojawiły się oskarżenia o rasizm, SPORT.TVP.PL, 11.09.2018, https://sport.tvp.pl/38944691/us-open-usciekla-serena-williams-bohaterka-karykatury-pojawily-sie-oskarzenia-o-rasizm (dostęp: 14.09.2018).

Serena Williams Cartoonist Mark Knight Defends 'Racist' Image, materiał filmowy, https:// wuw.youtube.com/watch?v=KrDQ_tBfUBE (dostęp: 14.09.2018).

Springer F., 13 pięter, Wydaunictuo Czarne, Wołowiec 2015.

Szczukouski D., Tomaszeuska G.B., Sztuka interpretacji a lekcje polskiego, „Polonistyka” 2013, nr 16(11). 
Maciej Zweiffel

Zalecenie Parlamentu Europejskiego i Rady z dnia 18 grudnia 2006 r. w sprawie kompetencji kluczowych w procesie uczenia się przez cate życie (2006/962/WE), https://eur-lex.europa. eu/legal-content/pl/TXT/PDF/?uri=CELEX:32006H0962 (dostęp:10.09.2018). 